Geoforum, Vol. 8, pp. 155-168, 1977. Pergamon Press. Printed in Great Britain.

\title{
The Potential for Natural Gas from the North Sea in Relation to Western Europe's Market for Gas by the mid-1980s
}

\author{
PETER R. ODELL, ${ }^{*}$ Netherlands
}

\section{Introduction}

The potential role of natural gas in the Western European energy market remains as perplexing now as it has been throughout the last decade. More than eight years ago I published a study, Natural Gas in Western Europe (ODE LL, 1969), which drew attention to the availability of a potential for gas production which far exceeded both the plans of operators and the expectations of governments in a situation in which there was no possible element of demand constraint on the potential to supply. The essential element that could then be identified in the European gas market was the existence of a monopoly supplier seeking to achieve the highest possible monopoly rent out of the remarkable phenomenon of the largest non-associated gas field in the non-Communist world: a gasfield, moreover - the Groningen field of the Netherlands - which lay in a concession allocated in its entirety to a joint enterprise of Shell, Esso and the Dutch government. The parties concerned were not only anxious to earn monopoly profits out of the production and sale of the gas as such, but were also jointly concerned with so restraining the sale of gas that their own interests in the maintenance of the markets for fuel oil and middle distillates would not be adversely affected.

I suggested that the strategy of the monopolists would be undermined by competition from alternative supplies, notably by the development of gasfields in the southern part of the British sector of the North Sea (and possibly in other sectors too), and also by

* Economic Geography Institute, Erasmus University, Rotterdam, Netherlands.

An earlier version of this paper was presented at the Financial Times/Norwegian Journal of Commerce and Shipping Conference on Oil and the Norwegian Economy in Oslo, April 22-23, 1977. the high-price gas market in Western Europe attracting surplus gas supplies from the Soviet Union, via pipelines from the massive West Siberia fields, as well as from other oil producing countries via the rapiḍly developing technology of liquified natural gas transport. In addition, I produced an alternative forecast of the shape of the West European gas market by 1975 based on these considerations. This forecast was an alternative to that made at the same time by the energy planners in the O.E.C.D., the E.E.C. and various national entities. The contrasts between these estimates, together with the situation as it had actually developed by 1975, is shown in Table 1 .

The purpose of these introductory comments is not to allocate "marks" for the degree to which the forecasts were right or wrong, but simply to indicate the landency, on the part of "officialdom", to produce estimates of the future supply of natural gas based either on a static view of the reserves situation or on an extrapolation of specific commercial and state policies which stand in danger of being undermined, at any time, by the forces of competition and/or change in the general energy and economic environment.

\section{The Importance of Natural Gas in the West European Energy Economy}

The above statement is as true today as it was a decade ago: indeed, probably even more so than it was then, because more governments and more companies have got involved thus making the situation even more complex to analyse. This has had the effect of encouraging even more of the actors to pursue policies and to take decisions which, in essence, try to limit the scale and speed of development of the resource. In addition, there is one other factor which now intervenes to isolate the evolution of the natural gas market from considerations of supply and demand schedules 
Table 1

- Western Europe: 1969 estimates of natural gas production by 1975

\begin{tabular}{|c|c|c|c|c|}
\hline Country/Region & $\begin{array}{l}1968 \\
\text { Production }\end{array}$ & $\begin{array}{l}\text { Official } \\
\text { Estimates } \\
\text { for } 1975 \\
\qquad\left(\mathrm{~m}^{3}\right.\end{array}$ & $\begin{array}{l}\text { Author's } \\
\text { Estimate } \\
\text { for } 1975 \\
0^{9} \text { ) }\end{array}$ & $\begin{array}{l}\text { Actual } 1975 \\
\text { (approx.) }\end{array}$ \\
\hline $\begin{array}{l}\text { The Netherlands } \\
\text { (of which Groningen) }\end{array}$ & $\begin{array}{l}25.1 \\
(25.1)\end{array}$ & $\begin{array}{l}55 \\
(55)\end{array}$ & $\begin{array}{l}118 \\
(100)\end{array}$ & $\begin{array}{l}98 \\
(92)\end{array}$ \\
\hline $\begin{array}{l}\text { West Germany } \\
\text { (of which on-land) }\end{array}$ & $\begin{array}{l}5.8 \\
(5.8)\end{array}$ & 15 & $\begin{array}{l}25 \\
(20)\end{array}$ & $\begin{array}{l}20 \\
(20)\end{array}$ \\
\hline $\begin{array}{l}\text { South North Sea } \\
\text { (British/Danish Sectors) }\end{array}$ & 2.3 & 30 & 38 & 37 \\
\hline Italy & 10.4 & 12 & 20 & 15 \\
\hline
\end{tabular}

France

8.7

6

10

11

Rest of Europe

$<1$

2

5

2

$\begin{array}{lllll}\text { Total } & 53 & 120 & 217 & 183 \\ \text { (Estimates as \% of actual) } & & (65 \%) & (117 \%) & \end{array}$

Source : 1969 estimates from P.R. ODELL, Natural Gas in Western Europe (DE ER VEN F. BOHN, Haarlem, 1969). 1968 and 1975 "actuals" from

F.F.C. and national statistics.

as determined by competition in the energy market place. This is the existence of a more or less general belief that natural gas is an inherently scarce commodity such that the discovery of any of it must be viewed in the context of saving it for the 21 century when, so it is argued, it will be needed to provide a little residual light and warmth in a world otherwise devoid of readily available and usable sources of energy -- in brief, the scarcity syndrome; a response to the first and ill-considered report of the Club of Rome and to the stories of gas shortages in presentday United States.
No one in his right mind would advocate profligacy in the use of a fossil fuel, especially natural gas with its many advantages over the alternatives. But it is a far cry from such advocacy to a plea for a reasonable view on the development of the Western European natural gas market based on the following considerations:

(a) The continent of Europe needs to reduce its dependence on oil imported from OPEC countries in the interests of security, both economic and political. Energy policies of individual countries, as well as of organisations 
like the E.E.C. and the I.E.A., are supposed to be changing economies and societies in such a direction. Yet the existence of known natural gas resources in and around Western Europe could, if they were developed effectively, remove an additional 50 million tonnes a year off the region's oil imports within the short space of time needed to develop the infrastructure to get the gas into the transmission systems.

(b) Europe stands almost at the beginning of its search for hydrocarbons and so far, in relation to the total potential, very little has been achieved. It is thus inappropriate, to say the least, for Western Europe to approach the question of reserves' decline and resource exhaustion in the same way as is currently necessary in the United States, for example, where the nation's reso urces have been thoroughly explored and exploited over the last 50 years. The appropriate lesson to be drawn from the U.S., is to note how quickly reserves build up during the first twenty to twentyfive years of an effective exploration effort.
On this basis, it is possible to extrapolate a continuing rapid development of Western Europe's gas resource base and plan depletion against reasonable expectations of reserves' discoveries, rather than against the amount of gas discovered up until a particular year.

(c) Such an approach to the evolution of a gas reserves' figure does not, necessarily, have to be based on analogy from United States' experience. It can be more soundly based on the prospects in view from what is already known about the resource base in Western Europe itself, or on what can, with a reasonable degree of confidence, be extrapolated from the successes, to date, of the exploration effort. What such a survey shows, is that there is a high probability that the currently proven and probable reserves of gas a re understated, and that available reserves will go on increasing during the foreseeable future, even after allowing for the gas whicn is being, and will continue to be, used with'n the context of what has now become a relatively slowly rising demand curve. This is illustrated in Table 2, which also seeks to establish possible

\section{Table 2}

- Western Europe: it's "Proven" and possible natural gas resources and an estimate of their development by the early $1980 \mathrm{~s}$

\begin{tabular}{|c|c|c|c|c|c|}
\hline & \multicolumn{3}{|c|}{$\begin{array}{l}\text { Remaining Recoverable } \\
\text { reserves }\end{array}$} & \multirow{2}{*}{$\begin{array}{l}\text { Mid-1980s } \\
\text { annual } \\
\text { production } \\
\text { potential }\end{array}$} & \multirow{3}{*}{$\begin{array}{l}\text { Millions of } \\
\text { tons of coal } \\
\text { equivalent* } \\
\text { (approximate) }\end{array}$} \\
\hline & $\begin{array}{l}\text { Declared } \\
\text { 'Pruven' } \\
+ \text { 'Probable' } \\
\text { in } 1976\end{array}$ & $\begin{array}{c}\text { Proven + } \\
\text { Probable } \\
+ \text { Possible }\end{array}$ & $\begin{array}{c}\text { As likely to } \\
\text { be available } \\
\text { by early } \\
1980 \mathrm{~s}\end{array}$ & & \\
\hline & $\left(x 10^{9} \mathrm{~m}^{3}\right)$ & $\left(x 10^{9} \mathrm{~m}^{3}\right)$ & $\left(x 10^{9} \mathrm{~m}^{3}\right)$ & $\left(\times 10^{9} \mathrm{~m}^{3}\right)$ & \\
\hline On-shore Netherlands & 2030 & 2150 & 2100 & 105 & 110 \\
\hline $\begin{array}{l}\text { South North Sea - } \\
\text { British Sector }\end{array}$ & 550 & 725 & 1050 & 50 & 65 \\
\hline $\begin{array}{l}\text { South North Sea- } \\
\text { Other Sectors }\end{array}$ & 440 & 850 & 1250 & 55 & 70 \\
\hline On-Shore West Germany & 310 & 515 & 450 & 25 & 30 \\
\hline Austria, France, Italy, etc. & 420 & 490 & 600 & 35 & 45 \\
\hline $\begin{array}{l}\text { Northern North Sea Basin- } \\
\text { U.K./Norway }\end{array}$ & 900 & 1500 & 2500 & 115 & 145 \\
\hline \multirow{2}{*}{$\begin{array}{l}\text { Rest of European Continental } \\
\text { Shelf (Ireland, Spain, etc.) }\end{array}$} & 50 & 150 & 350 & 20 & 25 \\
\hline & 4700 & 6380 & 8300 & 405 & 490 \\
\hline
\end{tabular}

Source: For 1976, various national and E.E.C./O.E.C.D. estimates. Estimates for the 1980s are the author's own. * Conversion to coal equivalent based on known or estimated calorific values of the various gas supply sources. 
elements of controversy in contemporary "crystal-ball gazing" concerning the future supply of, and demand for, natural gas in Western Europe by the middle of the 1980s.

\section{The Demand for Natural Gas}

Within the context of OPEC oil at high prices, there is no expectation that any natural gas which could be produced in Western Europe would fail to find markets. Obviously a collapse of the OPEC oil price would significantly alter this assumption. In that case, many customers in a continued free-choice economy in the energy sector, might then prefer to use imported lower cost oil, than pay the price necessary to cover the costs of producing and transporting some of the more expensive off-shore gas to market. Such a development would limit natural gas markets throughout the continent, especially in industry and in power generation, and would clearly be most important in consuming regions furthest away from the main sources of natural gas supply. This surply is, as shown in Figure 1, essentially north-west European. For the moment, however, it is difficult to envisage such a fundanertal change in the world oil outlook and it is possible, therefore, to assume that, except locally and in particular circumstances of gas saturation of specific markets (e.g. the residential sector market in the Netherlands or, increasingly, in large parts of the U.K.), there are unlikely to be effective demand restraints imposed through economic factors on the expansion of the natural gas industry. Such an assumption is, of course, dependant on the absence of a long-lived economic depression in Western Europe.

Neither is it reasonable to conclude that there will be really significan t political/environmental constraints, except in the case of limitations on the use of gas in electricity power stations. (These restraints, incidentally, are produced by the belief that it is wasteful to use gas as the energy input into centralised electricity generating stations where only 35 per cent of the input fuel is converted in to useful energy, the rest being dispersed in to the atmosphere or in the cooling water.). Finally, neither is there a high probability that the necessary infrastructure to transport and distribute gas cannot be built. In this aspect, however, one does approach much clcser to the question of production limitatiors, particularly in respect of associated gas from oilfields. This possibility will be considered later in this paper as part of an examination of the supply side of the equation.

Overall, however, it is difficult to foresee any likely demand limitation on the use of natural gas in Western Europe for at least the next ten years. Its advantages as a source of energy are well-known and generally recognised and its incorporation into the energy economy at the maximum rate of development that the expansion of the production potential allows, remains now, as it did in 1969 , a function of the geography of its supply and the location of energy demand. This is illustrated in Figure 2 which I first used in my 1969 study, with the following note of explanation:
"In both the U.S. and the USSR the main energy consuming areas are remote from natural gas supplies and despite these facts of geography gas has become a preferred fuel in both countries. Within western Europe, on the other hand, the major supplies of natural gas are in the heart of the areas of heaviest energy consumption. Other things being equal, this situation should ensure the most rapid development and utilisation possible of western European gas with consequent enhanced economic advantages for the continent's energy. users." (ODELL, 1969, p. 9).

\section{The Supply of Natural Gas}

The continuing basic validity of this earlier observation on gas in Western Europe is not in doubt: though there are some constraints on its manifestation because, in the Western European context, "other things have not been equal". For example, as was mentioned earlier, there have been institutional (monopolistic) restraints on the production of Dutch natural gas. Now, almost a decade later, one can note a major difference between the production potential, which the resource base development appears to indicate should be possible by 1985, and the figures which "officialdom" this time in the shape of the latest O.E.C.D. figures for energy supply and demand in Western Europe to 1985 (O.E.C.D., 1977) -... believes will be achieved (see Table 3). The O.E.C.D. estimates of 


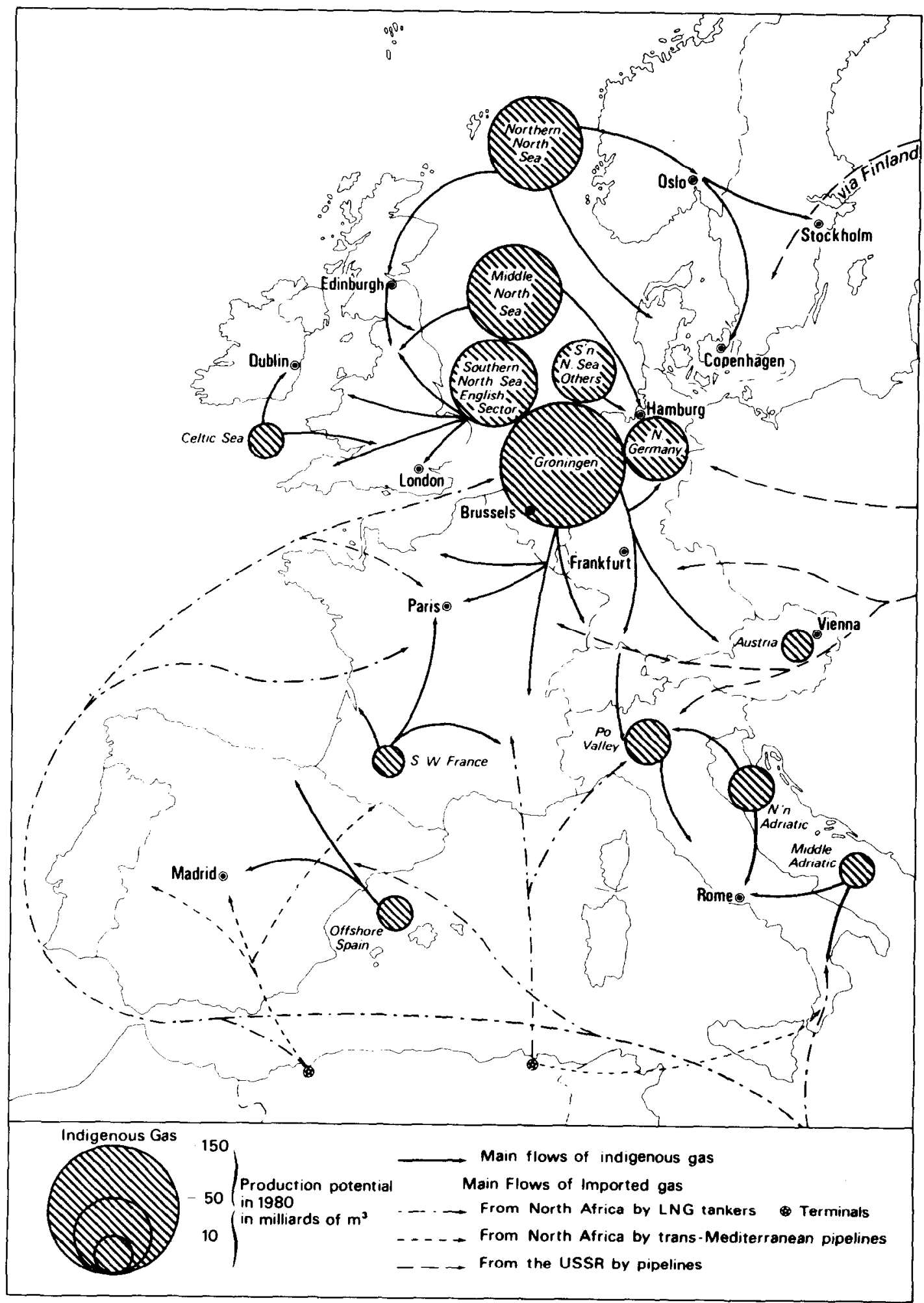

Figure 1

- The gengraphy of Western Europe's potential supplics of natural gas in the early 1980 s. 


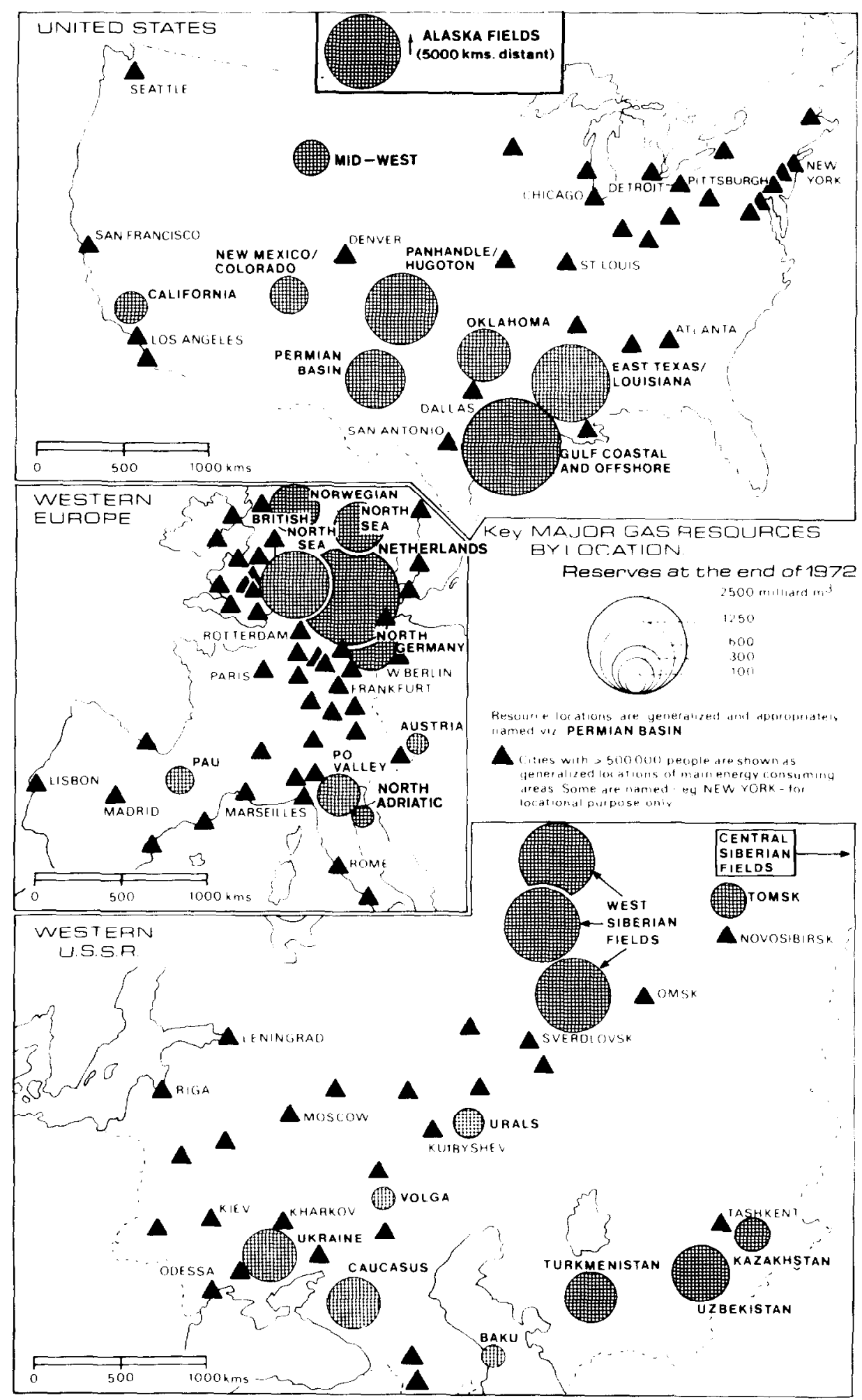

Figure 2

- The location of West European gas production in relation to energy demand centres compared with the United States' and Soviet Union's situations. 
Table 3

- O.E.C.D. forccasts of changes in energy consumption in Western Europe 1974-1985

\begin{tabular}{|c|c|c|c|c|c|c|c|c|}
\hline & \multirow{2}{*}{\multicolumn{2}{|c|}{$\begin{array}{c}1974 \\
\text { Energy Use }\end{array}$}} & \multicolumn{6}{|c|}{1985} \\
\hline & & & \multicolumn{3}{|c|}{ Reference } & \multicolumn{3}{|c|}{ Accelerated Policy Case } \\
\hline & Quantity & $\begin{array}{l}\text { \% of Total } \\
\text { Energy }\end{array}$ & Quantity & $\%$ of Total & $\begin{array}{l}\text { \% Increase } \\
\text { over } 1974\end{array}$ & Quantity & $\%$ of Total & $\begin{array}{l}\% \text { Increase } \\
\text { over } 1974\end{array}$ \\
\hline \multicolumn{9}{|l|}{ Oil (mill.b/d) } \\
\hline Natural Gas & 13.3 & $56 \%$ & 18.0 & $53 \%$ & $36 \%$ & 14.6 & $45 \%$ & $10 \%$ \\
\hline $\begin{array}{l}\left(\mathrm{m}^{3} \times 10^{9}\right) \\
\text { (of which W. Europcan }\end{array}$ & 174.4 & $13 \%$ & 311.8 & $15 \%$ & $79 \%$ & 341.9 & $18 \%$ & $97 \%$ \\
\hline Production) & $(157.7)$ & $(11 \%)$ & (228.9) & $(11 \%)$ & $(45 \%)$ & $(257.9)$ & $(13 \%)$ & $(63 \%)$ \\
\hline Coal (mill. tons) & 467.9 & $27 \%$ & 516.0 & $20 \%$ & $10 \%$ & 552.6 & $23 \%$ & $18 \%$ \\
\hline $\begin{array}{l}\text { Primary Electricity } \\
\text { (terawatt hr./yr.) }\end{array}$ & 1426.3 & $4 \%$ & 2593.0 & $12 \%$ & $82 \%$ & 2528.0 & $14 \%$ & $77 \%$ \\
\hline $\begin{array}{l}\text { Total Energy Use } \\
\text { (mill. tons oil equiv.) }\end{array}$ & 1159 & - & 1704.4 & - & $47 \%$ & 1619.2 & & $39 \%$ \\
\hline
\end{tabular}

Source: O.E.C.D., The Outlook for Energy to 1985, Paris, 1977.

$229-258 \times 10^{9} \mathrm{~m}^{3}$ of gas production should be compared with the potential for a production of over $400 \times 10^{9} \mathrm{~m}^{3}$ which emerges from the analysis shown in Table 2.

It is not that the O.E.C.D. figures for the future production of natural gas are so very pessimistic when compared with the 1974 base. As Table 3 shows, within the context of an expected 47 per cent increase in energy use in Western Europe over the period 197485, the O.E.C.D. 'reference case' allows for a natural gas production increase of 45 per cent, and for one of over 63 per cent in its "accelerated policy" case, which contains as one of its central elements, a stimulated level of natural gas production. However, the expectation of 1985 production levels of 229 and $258 \times 10^{9} \mathrm{~m}^{3}$ respectively, contrasts strongly with the estimated production potential from the still rapidly developing resource base. Indeed, as is shown in Table 4 , the difference between what is officially expected and what
I estimate to be possible, is of the same order of magnitude as the difference which existed between the estimates made in 1969 for production levels by 1975 (see Table 1). In both cases the official view indicates an increase in indigenous production which is no more than 40 per cent of the increase which could be sustained by full exploitation of the resources. It would be tempting to speculate that history, in this respect, is simply being given a chance to repeat itself. Indeed, one can argue that the same behavioural characteristics of official forecasters of the natural gas sector of the West European economy are again at work, in terms of their inability, or unwillingness, to think in dynamic enough terms about the development of the gas resource base under the stimulus of an open-ended demand. Alternatively, one could argue that O.E.C.D., as a multi-national energy planning agency, is most influenced in its published forecasts by the reticence of member governments to 
commit their countries to the maximum possible production of natural gas. This is because such a commitment implies either too large a rate of export to neighbouring countries so creating possible uncertainty over the likely availability of supplies of gas for domestic markets into the 21 century), or, even more simply, too high a rate of production when set against other national policy decisions. Such decisions may, as a matter of principle, simply seek to curb the rate of development of hydro-carbons, or they may be related to pre-existing plans for other sectors of the national energy economy (viz. coal, nuclear power). which are supported by powerful pressure groups that would not wish to see these other sectors under-mined by the prospect of too much gas.

It is, indeed, to one or other of these factors that one has to turn in order to find an adequate explanation for the continued under-estimating of the potential for indigenous natural gas in the Western European economy: rather than to really serious doubts over the size of the resource base which could be developed, or to equally serious doubts over the ability of the industry to produce and deliver the commodity, even from the adverse environments of the northern parts of the North Sea.
Table 4 summarises, by country, the differences between the O.E.C.D. "Reference" and "Accelerated" cases, on the one hand, and the production potential estimates previously listed in Table 2 , on the other. The Netherlands, the U.K. and Norway are, in all cases, the dominant suppliers. The differences in the estimates for these countries are thus critical in the analysis of the overall situation. Before dealing with these in detail, it is worth observing that in no other country is there an official expectation that the 1985 production levels will owe anything to discoveries which have not yet been made, other than relatively small developments in reserves which will be necessary to maintain production levels in countries like France and Austria. This is truly remarkable, given that every country on the list plans an active exploration programme for natural gas in potentially petroliferous regions in which there must be some hope of success, for otherwise no company or state entity would be willing to invest. A situation in which none of the hopes are realised is unbelievable, but illustrates nicely one of the basic points made carlicr about the failure of Western European governments to respond to the well-known dynamics of resource exploration and exploitation. However, the difference between the estimates for all

Table 4

- Western Europe: 1977 estimates of natural gas production by 1985

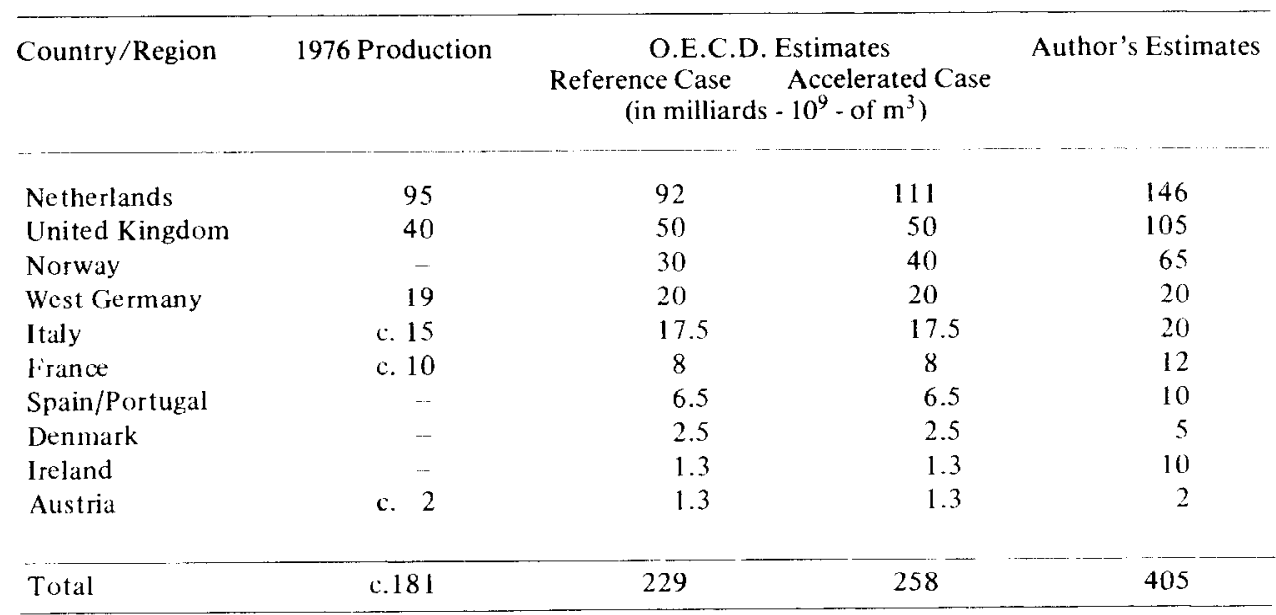

Sources: O.E.C.D. estimates from that Organisation's publication, The Outlook for Energy to 1985 . Paris, 1977. The author's estimates are based on production potential from gas reserves already discovered or likely to be available by 1980 so that there is time for the necessary production/transportation infrastructure to be built. See Fig. 1 for a map of the author's estimate of supply patterns by the early $1980 \mathrm{~s}$. 
Table 5

- Natural gas resources of the Southern North Sea Basin (excluding associated gas)

\begin{tabular}{|c|c|c|c|}
\hline & $\begin{array}{l}\text { Dutch } \\
\text { Sector }\end{array}$ & $\begin{array}{l}\text { British } \\
\text { Sector }\end{array}$ & $\begin{array}{r}\text { German } \\
\text { Sector }\end{array}$ \\
\hline Total number of Gas Discoveries & 51 & 31 & 3 \\
\hline Number of Discoveries Declared as Gas Fields & 11 & 15 & - \\
\hline $\begin{array}{l}\text { Governments' Declaration of Remaining Proven } \\
\text { Gas Rescrves }\left(10^{9} \mathrm{~m}^{\mathbf{3}}\right)\end{array}$ & $322 *$ & $552 *$ & - \\
\hline Number of Fields in Production & 2 & 7 & \\
\hline Other Fields with announced Production Plans & 8 & - & - \\
\hline Current (1976) Annual Production $\left(10^{9} \mathrm{~m}^{3}\right)$ & c. 3 & c. 40 & - \\
\hline $\begin{array}{l}\text { Estimate of } 1980 \text { Production from Fields currently } \\
\text { on production or in development }\left(10^{9} \mathrm{~m}^{3}\right)\end{array}$ & c. 10 & c. 42 & - \\
\hline $\begin{array}{l}\text { Likely Remaining Reserves for all fields in each } \\
\text { sector at summed } 90 \% \text { probability }\left(10^{9} \mathrm{~m}^{3}\right)\end{array}$ & $1000+$ & $1050+$ & $50+$ \\
\hline $\begin{array}{l}\text { 1980s Production Potential with Full Exploitation } \\
\text { of the already discovered reserves }\left(10^{9} \mathrm{~m}^{3}\right)\end{array}$ & $40+$ & $50+$ & $2-3$ \\
\hline
\end{tabular}

\footnotetext{
Notes: *Arithmetic total of "proven" reserves of declared fields. Based on all discoveries made and not just on declared fields. Based on 20 - 25 year depletion periods for the fields.
}

these minor producers together amounts to less than $30 \times 10^{9} \mathrm{~m}^{3}$ by 1985 . By contrast, for the Netherlands, the U.K. and Norway, the difference in the estimates is, in each case, at least that great.

As far as the Netherlands is concerned the discrepancy between the estimates is largely a function of contrasting expectations concerning the off-shore potential, though there is also a component relating to my expectation that the possible decline of production from the giant on-shore Groningen field will be more than made up by the exploitation of new on-shore resources which are now being found in the Netherlands as a result of an active exploration effort. The 'gap' in the interpretation of the offshore situation is, however, more important and emerges out of the information set out in Table 5 and Figure 3 . These show that the southern North Sea is full of gasfields and discoveries. About 30 are shown in the Dutch sector on the map, whilst the more recently compiled information in Table 5, indicates 51 discoveries. Thus, the official figure of a production of only 10 milliard $\mathrm{m}^{3}$ a year by 1985 is almost ludicrously low, even based, as it is, only on gas to be produced from the small number of officially declared fields. Yet in 1977, exploration for new gas fields in the Dutch sector seems likely to reach a record level as companies at last respond to the opportunity of the market for gas at prices which Dutch consumers now consider to be extraordinarily high (domestic gas prices in the Netherlands have more or less quadrupled over the last 3 years).

Indeed, given information now available, and that is little enough given the high degree of secrecy maintained in respect of Dutch gas reserves, and what one can confidently extrapolate, a level of production of less than $40-45 \times 10^{9} \mathrm{~m}^{3}$ per annum from the Dutch off-shore reserves by 1985 will only be possible within the context of unwillingness, on the part of the government, to allow reasonable developments to go ahead. Supply, in other words, will be constrained by an even more powerful institutional force than the N.A.M. monopoly over Groningen production in 1969.

For the U.K. the situation is rather different and somewhat more complex. Three main factors are involved. Firstly, developments in the British sector of the southern North Sea (see Figure 3 ) are curtailed by the lack of incentives to the companies which have so far discovered a large number of fields in the area. Any gas from these fields has to be sold "at the beach" to the British Gas Corporation and, as it is not prepared, or not allowed, to pay a price which enables the companies to meet the opportunity costs on the investments 


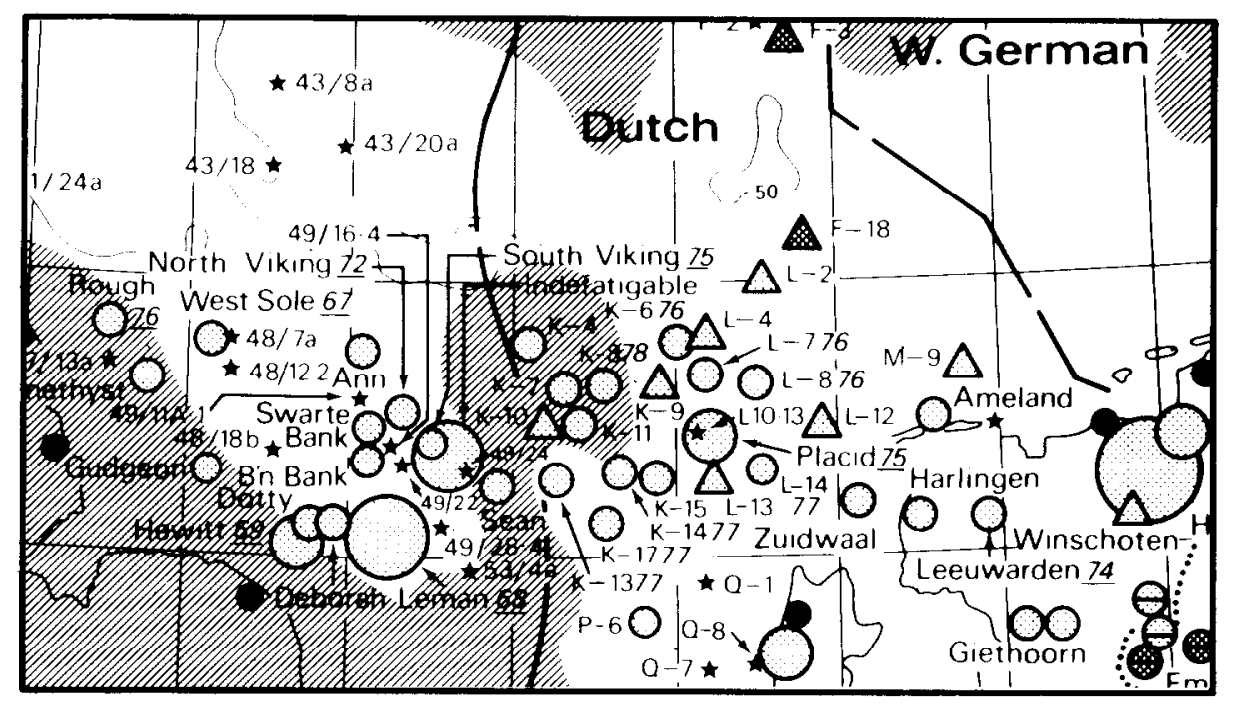

Figure 3

- Oil and gas fields and discoveries in the Southern Basin of the North Sea Oil province (see Figure 5 for the key to the symbols on the map).

required for the development of new fields, or even for the development of additional reserves from fields already in production, exploitation is not taking place and so reserves remain unproven and unused. This gas, together with that under the adjacent Dutch sector of the south North Sea, currently constitutes Western Europe's lowest-cost energy resource potential. Due to quirks of both Dutch and British policy, the benefits to be gained from its development are being foregone.

Secondly, the U.K.'s Gas Corporation tied itself, some years ago, to an open-ended commitment (both in quantity and price terms) to buy natural gas from the large Frigg field beneath Norwegian waters. ${ }^{1}$ (See Figure 4).

1 The reason for accepting such a commitment on the part of the B.G.C. -.. in the light of lower cost gas availability from the south North Sea basin and a high expectation of gas reserves heing discovered in British waters further north (as has now happened) - has never been satisfactorily explained: it seems to lie in the belief, by the former Chairman of the Corporation, that he was dealing with a scarce commodity and was concerned that he would not be able to cover his forward sales. This reasoning also explains why the B.G.C. stopped trying to sell gas to new customers - indeed, even refused to supply new customers ... at the same time. These mistakes have cost the B.G.C. dearly in respect of both its supply costs and its sales revenues.
Both the cost of this new gas and its annual availability, (at least $15 \times 10^{9} \mathrm{~m}^{3}$ per year, which adds about 35 per cent to the present level of supply), creates cause for concern over the ability of the Gas Corporation to market it successfully. This arises because the Corporation is well aware that it cannot expect to be allowed to sell any gas for electricity generation because its use would upset the one secure market for British coal. Thus, in concentrating on the marketing problem for Frigg gas (which, of course, imposes immediate and near-future cash-flow problems for the Corporation), it has to be less than fully enthusiastic about the rapid development of the even greater new production potential from the northern part of the British sector of the North Sea. Here many new oilfields with high gas oil ratios have been discovered so opening up the possibility of high annual rates of associated gas production by the early 1980 s.

This leads on to the third factor involved in creating the apparent unwillingness, on the part of the U.K., to declare its production potential for 1985 at a higher figure than the $50 \times 10^{9} \mathrm{~m}^{3}$ designated in the O.E.C.D. study. It concerns the expensive question of the development of a multi-user pipeline system for collecting associated gas from the 30 or so north North Sea oilfields with collectable quantities of natural gas (see 
Figure 5). This is partly a matter of expensive technology per se, but it is also a matter of politics, given the present Labour government's insistence that the operation should mainly be a state enterprise so that the private sector companies involved cannot be certain that they will achieve an adequate return on the investment they are required to put up. Detailed studies on the project are already under way and though urgency has been indicated, the required studies may be a way of buying time so that an appropriate policy can emerge. This is, however, not only time which may give the U.K. Gas Corporation a little breathing space for its new marketing efforts,but also time that may be expensively bought, either at the cost of oil production which has to be foregone, or of the associated gas that has to be flared. ${ }^{2}$

Indeed, so great are the difficulties involved when new supplies of British North Sea gas are viewed solely in a British context, that it appears self-evident that the best solution must lie in the U.K. linking its gas transmission system to that of the mainland of Western Europe, i.e. across the Channel into France and/or Belgium. And yet this solution is, in itself, a problem because of the idea that the U.K. should not commit itself to longterm gas supply contracts for other member countries of the E.E.C.. The British government once before, in 1971, refused to allow British gas (from the Viking field in the southern part of the North Sea) to be sold abroad. Even now, in spite of E.E.C. legislation which formally forbids discrimination between E.E.C. customers for any product from a member country, it seems likely that a similar decision would again be made. In the meantime, the potential for natural gas production from the U.K. will probably be restrained again, as in the case of the Netherlands, largely for institutional rather than sound economic or strategic reasons.

This discussion has left until last a consideration of the Norwegian situation with regard to its gas producing potential. In respect of this, the O.E.C.D. forecasts specify the greatest proportional difference between the 1985 "Reference" case and the "Accelerated

2 The Dept. of Energy's announcement at the end of June 1977 that part of the Brent oilfield must be closed down until associated gas production can be collected nicely illustrates this point.
Policy" case, with the latter indicating a 33 per cent higher availability than the former. Even so, the "Accelerated Policy" indicates so low a figure that it will take deliberately negative policies with reference to the potential available for it not to be exceeded. But it is, of course, such policies in respect of hydro-carbon production levels, which epitomise Norwegian attitudes towards its North Sea gas resources. If all considerations have to be evaluated in the light of the general principle that the total production of hydro-carbons by Norway shall not exceed the equivalent of 90-100 million tons of oil per year then, given the reserves that have been found already, together with what is under development on both the oil and gas fronts, the production of natural gas cannot rise above the $30 \times 10^{9} \mathrm{~m}^{3}$ per year level. The rest of the

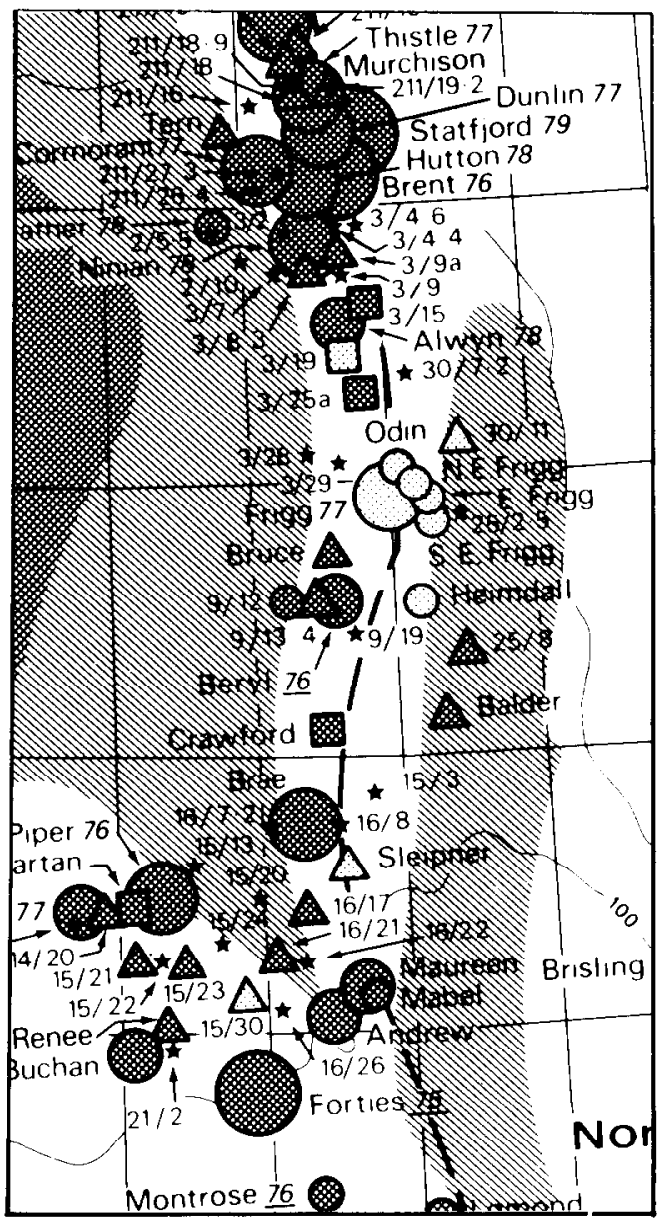

Figure 4

- Oil and gas fields etc. in the Northern Basin of the North Sea. 


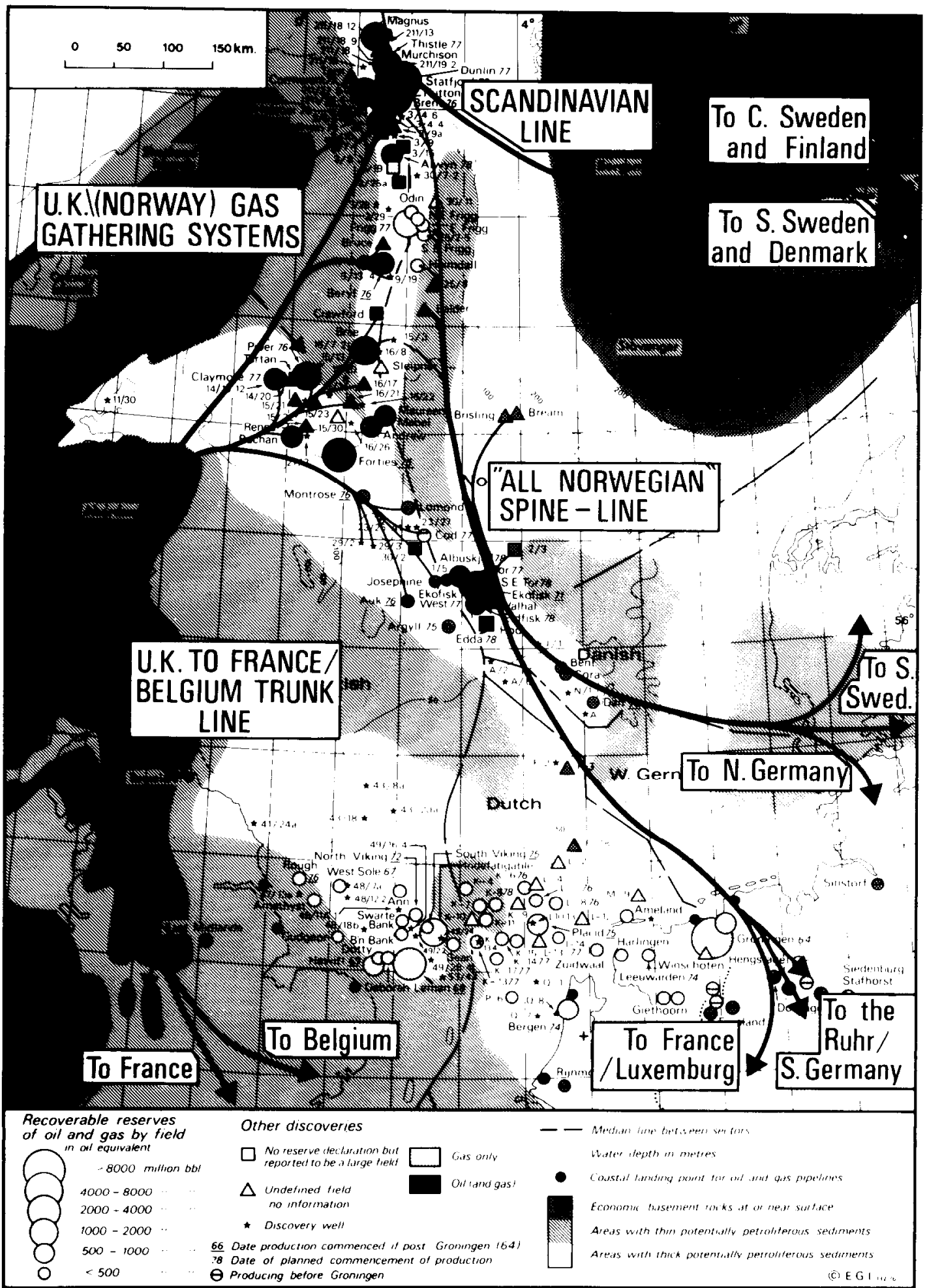

Figure 5

- The North Sea oil and gas province. Fields and discoveries etc. to December 1076 and alternative possibilities for natural gas collection and delivery systems from the Northern and Central Basins. (N.B. The gas transport systems are hypothetical only: they do not represent definite plans in general or in detail as at March 31.1977). 
allowed hydro-carbon production "quota" will be absorbed by oil from Ekofisk, Statfjord and other fields already proven.

I have previously commented, somewhat critically, on this main element in Norwegian oil and gas policy, especially when it is seen in the context of a western Europe whose political and economic future is heavily dependent on greatly reducing its dependence on oil from the Middle East. ${ }^{3}$ I have also suggested that the internal Norwegian reasons for formulating the policy decision in 1973 have long been overtaken by events, particularly in respect of the no longer valid assumption, as used in the calculations of the optimal level of Norwegian hydro-carbons production, that all the country's resources would be fully employed in other economic activities. The decision on production limitation has not been formally reversed but there are recent indications that it is being seriously re-evaluated. It is not appropriate to delve here into the reasons for the change in attitude: a change which is reflected, for example, in the licensing of a relatively large number of new blocks in the North Sea and in the decision, in early 1977, to allow exploration north of latitude $62^{\circ}$ to begin in $1978 .^{4}$ The change, however, does open up the possibility of re-appraising the level of natural gas production that could be achieved by Norway by the mid-1980s. Fields still to be evaluated, together with those that are still to be discovered over the next three to five years, contribute to the enhanced potential which may be conservatively put at the level of $65 \times 10^{9} \mathrm{~m}^{3}$ as shown in Table 4 .

As much of the potential is in respect of associated gas, from fields such as Statfjord, the production decision is often a joint one involving oil as well as gas. Thus technical, rather than marketing, considerations are often paramount. If the gas "has" to be sold, rather than reinjected or flared, then transport considerations, particularly with respect to pipeline distance under water and the scale of the operation, may well be an

3 See P. R. ODELL, Norway's Oil and Europe's Energy Needs; Bases for a mutually advantageous development policy, Financial Times Conference on Scandinavia and the North Sea, Oslo, 29 April 1974.

4 This decision, however, has been 'put on ice' pending a thorough investigation into the Ekofisk field "blow out" in May 1977 and for further study of environmental questions. overall determining factor for the volume which has to be involved. Given the location of Statfjord and other possible contributing fields, to an enhanced supply of Norwegian gas (see Figure 5), the quantities would seem likely to have to be larger rather than smaller.

If a 'Norwegian' solution to the Norwegian north Sea gas potential is to be achieved, through the development of the north-south "spine-line" which could link a series of fields in Norwegian waters with Germany and/or Denmark (see Figure 5), then a delivery system with a capacity for upwards of $20 \times 10^{9} \mathrm{~m}^{3}$ per annum seems likely to be required in order to keep the unit investment cost down to a level which ensures the marketability of the gas. This, when added to existing contracts, would take Norway's contribution of gas to the European market above even the 'Accelerated Policy' figure in the O.E.C.D. report. Such a system is attractive, not only because of the 'Norwegian-ness' of the solution, but also because it ensures entry to the high-gas demand areas of West Germany and other mainland markets, where an oil equivalent price would be an acceptable formula for determining the gas price.

This, however, is not true in the case of the alternative solution, that is, the building of a system of collector pipelines from the Norwegian fields to tie into the proposed multi-user trunk gas lines running from fields in the British sector of the north North Sea to the U.K. mainland. In this case Norway could get away with a more limited scale of development, but only in exchange for difficult negotiations with the U.K. over the charges to be made for the use of the British lines and for using the U.K. as a transit state if there were to be an attempt to get the Norwegian gas delivered to the mainland of Western Europe via the U.K. Not that such a development would be without benefits to the U.K. Indeed, two sets of benefits would arise. First, there would be the general added value to the British economy of this service function with, most specifically, the Norwegian throughput of gas in the British trunk lines more or less guaranteeing the short-term viability of the multi-user line project. Second, the U.K. would benefit in terms of the political opening that the transhipment of Norwegian gas to France, or Belgium, would give to a British government so that it could 
'sell' the idea that some British gas could also move across the Channel, at both low cost and high value in terms of foreign exchange earnings to the U.K. economy.

Such Anglo-Norwegian co-operation might thus enable Norway to restrict its supply of natural gas to a level lower than appears to be necessary if Norway is to go it alone in creating the transportation system required to ensure the profitable development of its own gas resources. A decision on this may well be the main element involved in determining whether Norway does nothing more than expected by the O.E.C.D. energy analysis, or whether it chooses to move to a level of supply by 1985 which will take its total production of oil and gas beyond the previously determined upper-limit of the 1973 plan. This choice by Norway also depends on its own institutional response to the challenge and opportunities presented by the natural gas markets of Western Europe, the same sort of choice as has already been shown to be the case in respect of the other two main suppliers of this form of energy to Europe's needs and demands.

\section{Conclusion}

The Netherlands, Britain and Norway thus have much in common in their near-future relationships with the rest of Western Europe, particularly in terms of their ability and their responsibility to determine just how independent the region can become from O.P.E.C. oil in the 1980s. Let us assume that all three decide to pursue policies that maximise. rather than restrict, the production of their large natural gas reserves. Further, let us assume that all the additional natural gas will substitute oil that the O.E.C.D. currently expects will have to be imported from the O.P.E.C. countries. Then, within the context of the figures in the O.E.C.D. report on West Europe's total energy demand, and taking into account the total supplies of other sorts of energy available in Europe in 1985, the need for oil imports would fall from O.E.C.D. 's calculated 11.2 million $b / d$ to only a little over one third of this amount (roughly 4 million $b / d$ ), so making Western Europe, to all intents and purposes, independent of O.P.E.C. for its supplies of essential energy. This much, in respect of Europe's energy needs, is at stake when decisions on future levels of natural gas production are taken by Norway, Britain and the Netherlands.

\section{References}

ODELL P. R. (1969) Natural Gas in Westem Europe: A Case Study in the Economic Geography of Energy Resources. DeErven F. Bohn, Haarlem.

O.E.C.D. (1977) The Outlook for Energy to 1985. Paris. 